\title{
Intellectual property rights in the world economy
}

Citation for published version (APA):

Verspagen, B. (1999). Intellectual property rights in the world economy. MERIT, Maastricht Economic Research Institute on Innovation and Technology. MERIT Research Memoranda No. 016 https://doi.org/10.26481/umamer.1999016

Document status and date:

Published: 01/01/1999

DOI:

10.26481/umamer.1999016

Document Version:

Publisher's PDF, also known as Version of record

\section{Please check the document version of this publication:}

- A submitted manuscript is the version of the article upon submission and before peer-review. There can be important differences between the submitted version and the official published version of record.

People interested in the research are advised to contact the author for the final version of the publication, or visit the DOI to the publisher's website.

- The final author version and the galley proof are versions of the publication after peer review.

- The final published version features the final layout of the paper including the volume, issue and page numbers.

Link to publication

\footnotetext{
General rights rights.

- You may freely distribute the URL identifying the publication in the public portal. please follow below link for the End User Agreement:

www.umlib.nl/taverne-license

Take down policy

If you believe that this document breaches copyright please contact us at:

repository@maastrichtuniversity.nl

providing details and we will investigate your claim.
}

Copyright and moral rights for the publications made accessible in the public portal are retained by the authors and/or other copyright owners and it is a condition of accessing publications that users recognise and abide by the legal requirements associated with these

- Users may download and print one copy of any publication from the public portal for the purpose of private study or research.

- You may not further distribute the material or use it for any profit-making activity or commercial gain

If the publication is distributed under the terms of Article $25 \mathrm{fa}$ of the Dutch Copyright Act, indicated by the "Taverne" license above, 


\title{
InTEllectual Property Rights In THE WORLD ECONOMY
}

\author{
by Bart Verspagen \\ (ECIS, Eindhoven University of Technology, and MERIT, Maastricht University)
}

Eindhoven University of Technology, PO Box 513 DG 1.21, 5600 MB Eindhoven, Netherlands. Tel +31 40 2475613, fax +31 40 2474646. MERIT, PO Box 616, 6200 MD Maastricht, Netherlands. Tel +31 43 3883869, fax +31 43 3216518. Email: bart.verspagen@merit.unimaas.nl, web: http://meritbbs.unimaas.nl/verspagen.html

This paper contains two essays that were presented at the WIPO Arab Regional Symposium on the Economic Importance of Intellectual Property Rights, Muscat, Sultanate of Oman, February 22-24, 1999. Because of their interrelatedness, they are printed together as one working paper. I thank participants at the conference and Eddy Szirmai for useful comments and discussions. 


\title{
THE ECONOMIC IMPORTANCE OF PATENTS
}

\author{
by Bart Verspagen* \\ (ECIS, Eindhoven University of Technology, and MERIT, Maastricht University) \\ Paper for the WIPO Arab Regional Symposium on the Economic Importance of Intellectual \\ Property Rights, Muscat, Sultanate of Oman, February 22-24, 1999.
}

First draft, February 1999

\section{Introduction}

Intellectual property rights (IPRs) are high on the agenda of policy makers, academics and business firms. Now that knowledge and immaterial products are becoming more and more important in the world economy, IPRs are more crucial than ever. With rapid technological developments in many fields, policy makers are asking themselves how to adapt the existing systems of IPRs to the changing circumstances. What guidance can economic theory give them in this process?

In order to provide the answer to this question, it is necessary first to establish the economic function of patents. That will be the first question that this paper tries to analyze. It will be argued that patents, more than other forms of IPRs (such as copyrights and trademarks) are important for the dynamic performance of the economy.

The second question is how economic analysis can guide the design of a patent system. Here, issues such as the patent length (duration), breadth (scope of protection) and height (novelty requirements) are analyzed. Although there are many formal models of patent system design that can help in outlining the relevant economic processes, these do not offer, as will be argued below, very concrete guidance. The main reason is that these models are too abstract to be applied in practical terms. It will be argued that only detailed case studies of existing patents in combination with the study of technological systems can provide practical insights into how broad patents should be. Unfortunately, it is beyond the scope of this paper to delve into the details of the (legal) practice of IPRs, or outline detailed technological trends in relation to IPRs. Given the scope of the paper, the analysis will be limited to discussing the main, general insights economic theory can deliver.

The rest of this paper is organized as follows. Section 2 briefly outlines some developments in the economic theory on growth. It will be argued that patents play a crucial role in modern growth (theory). The section will also introduce the concept of technology spillovers. Section 3 will outline the economic functions of patents, and also introduce the concepts of patent breadth and patent length. Section 4 will come back to the issue of spillovers, and their link to patents. The issue of patent breadth will be analyzed taking into

\footnotetext{
* Eindhoven University of Technology, PO Box 513 DG 1.21, 5600 MB Eindhoven, Netherlands. Tel +3140 2475613, fax +31 40 2474646. MERIT, PO Box 616, 6200 MD Maastricht, Netherlands. Tel +31 433883869 , fax +31 43 3216518. Email: bart.verspagen@ merit.unimaas.nl, web: http://meritbbs.unimaas.nl/verspagen.html
} 
account the economic importance of spillovers. Section 5 will summarize the main line of argument.

\section{Technology and the economy}

The importance of technology for economic growth is obvious to anybody who has even a vague notion of the history of technology or the history of the world economy. The prolonged growth of GDP per capita (which, admittedly, is an imperfect measure of what matters for the quality of human life) since the (first) Industrial Revolution was made possible by a combination of entirely new processes and new products, which kept being introduced into the economy at what appears to have been an increasing rate (see, e.g., Landes, 1969, Maddison, 1991 and Freeman and Soete, 1997).

Despite the load of historical evidence, (mainstream) economic theory, however, until very recently, was not very comfortable with the relation between economic growth and technology. Formal theorists as economists are today, they were rather uneasy with the 'qualitative' work by 'pre-modern' economists such as Marx and Schumpeter', who had kept closer links with the historical evidence and given technology a central role in their analysis.

The dominant theory of economic growth (Solow, 1956) was based on the cornerstone of all modern economic analysis, namely that of 'decreasing marginal returns'. ${ }^{2}$ This notion refers to the fact that if one keeps adding more and more capital (machines, buildings) to a production process, the additional value added generated by this capital will keep falling, until it eventually becomes zero. This concept, which dates back to Marshall (1890), is very central in economic analysis because it enables the theorist to calculate the outcome of a rational decision making process. For example, it is possible to calculate the price that a firm will charge for its product when decreasing marginal returns apply, while this is generally impossible to do if this assumption is not made.

However, when marginal returns keep falling until they are zero, long-run economic growth is only possible if some 'exogenous' factor is assumed to be present. This could, for example, be technical change that falls as 'manna from heaven', or is given by 'God and the engineers'. Such exogenous factors, by definition, are not affected by economic decisions, and that is why economic models did not have very much to say about growth.

It was only recently (e.g., Romer, 1986, Grossman and Helpman, 1991) that economists were willing to admit that with technological change that is motivated by economic goals, the assumption of zero marginal returns in the long run was unable to maintain. Investment in technology and R\&D is a way to avoid them, and to keep returns to capital positive in the long run. This opened the way for a wholly new class of so-called 'endogenous growth models', in which long-run growth can be explained without resorting to exogenous

\footnotetext{
${ }^{1}$ Marx (1981), Schumpeter (1939).

${ }^{2}$ Readers are begged to bear with me for the brief excursion into some of the finer subtleties of economic theory that follows. As will hopefully become clear by the end of the Section, it will lead to the conclusion that patents, which are the central theme of this paper, are very important for the modern economic theory on growth.
} 
technological change. In these models, firms' decisions on research and development (R\&D) are taken into account, and patents on the outcomes of R\&D play a large role.

Although not all of the new growth models agree on this, some (e.g., Grossman and Helpman, 1991) argue that the mere existence of $R \& D$ by firms is not enough to solve the problem that decreasing marginal returns pose for economic growth. They argue that longrun positive economic growth is only possible when technological change displays so-called 'externalities' or 'spillovers'. By this notion, they refer to the idea that a technological invention is not only of use to its inventor, but also to other firms in the economy. The nature of technology, as will be argued in more detail in the next section, makes it possible that other firms than the original inventor can use (parts of) it as well.

Grossman and Helpman, as well as other 'new growth theorists' argue that without spillovers, long-run economic growth will cease. Although their models, as well as this specific proposition, remain to be tested empirically (e.g., Jones, 1995), their assertion clearly illustrates the importance of the spillover concept for the economy. The question arises, however, why a firm would invest in $R \& D$ if other firms may reap (part of) the benefits of this investment. Obviously, this is where a system of intellectual property rights (IPRs), more specifically a patent system, comes in.

\section{Patents as incentives for $R \& D$}

\subsection{The appropriability problem}

In a sense, technological knowledge is an economic good in which firms (and governments) invest money. Competition between firms is based on product quality (including service), and price. In both of these aspects of the competitive process, technology plays an important role. The price of a good depends on productivity and the costs of inputs such as labour, raw materials, machines and buildings. By enhancing productivity, technological change may lead to a dramatic fall of the price charged by the firm that implements such process innovations. Other firms in the same are then forced to drop their prices as well, or else they will be driven out of the market. How this may lead to dramatic price falls is illustrated well by an historical example quoted in Freeman and Soete (1997) (p. 60). Over the period 18701898 , the price of steel (in $\$$ per ton) fell by $83 \%$, or an average of almost $3 \%$ per year. This tremendous drop coincided with a period in which important innovations in steel making (most notably the Bessemer process) were applied in the American economy.

Investment in technological change may also be aimed at product innovation. Moore's law is perhaps the most famous example of rapid product innovation. Gordon Moore, the cofounder and chairman of the Intel corporation, predicted in the 1960s that the complexity (measured as the number of components put on one chip) of so-called integrated circuits would double each year. For the firm that was leading this development (i.e., Intel), this high rate of product innovation led to a dominating market position, which, nowadays, is challenged by only a handful of competitors. 
It would thus appear from such anecdotal evidence that firms have more than enough reason to invest in research and development $(R \& D)$ in order to increase their competitive position. Why then is a system of intellectual property rights necessary to stimulate investment in R\&D? The answer to this problem lies in the fact that technology has a number of special characteristics that are not often found in other economic goods. A normal economic good (say, an orange) is both rival and excludable. This means that only one person can consume or use the orange (rivalry), and the supplier of the orange can exclude persons from consuming it (i.e., those who are not prepared to pay for the orange). These two characteristics, which hold for the large majority of all goods in modern economies, ensure that these goods will be produced in a market economy. A farmer is willing to grow oranges because, due to the rival and excludable character of the orange, she is able to sell the oranges on the market, and earn a profit.

Technological knowledge is a good for which the characteristics of rivalry and excludability do not hold perfectly. Imagine a situation without intellectual property rights. If a firm would invest to develop a new chip, its competitors would be able to copy the knowledge embodied in this circuit by buying a single unit of the new product, and reverse engineer it. In other words, the knowledge embodied in the chip is non-rival (the fact that one firm uses it does not imply that other firms cannot use the same knowledge), and is nonexcludable (there is no way the inventor can exclude others from using the knowledge she developed, except for the trivial case that the knowledge is not used in any way).

There would thus be no incentive for a firm to invest in such knowledge. Without protection of its intellectual property, other firms can free ride on the efforts of the inventor, and, hence, assuming that imitation is cheaper than developing the invention, put the new product on the market for a far lower price than the original inventor. This is why non-rivalry and non-excludability poses a problem in terms of incentives to produce these goods.

Besides technological knowledge, there are a number of other goods that have the characteristics of non-rivalry and non-excludability. Examples are national defense and clean air (one cannot exclude individual citizens from either of those goods, and they can be consumed by numerous people at the same time). In economic theory, these goods are said to be characterized by market failure, i.e., a free market economy will either not produce these goods at all, or produce them in quantities far too small for the existing demand. National defense and clean air (as well as other examples one may think of) are goods that are usually supplied by public governments. This is why these goods are called public goods.

However, public provision is not the only way in which market failure of non-rival and non-excludable goods may be solved. The system of IPRs can be considered as an institution that tries to solve the problem of market failure by providing private producers with incentives to supply public goods. As such, a system of IPRs is thus one of the possibilities to solve the problem of market failures. The next section will provide an overview of all of these mechanisms, and discuss the advantages and disadvantages of IPRs (relative to the other means to solve market failure) in some detail. 


\subsection{Ways of stimulating invention}

David (1993) discusses the three P's of trying to solve market failure in the are of technological change: Patronage, Procurement and Property Rights (or Patents). All three mechanisms are actually used to stimulate the development of new knowledge in practice, although they are related to different parts of the R\&D infrastructure. The first P, Patronage, refers to the process where government finances a group of researchers to undertake $R \& D$, and thus provide new knowledge. This is the system that is most widely used for basic science, where publicly financed universities or public research labs play a large role in pushing forward the frontier of knowledge. Note that this is similar to the solution of market failure in the case of standard public goods such as defense.

Procurement refers to the process where governments engage in contracts over the development of a specific piece of knowledge. Thus, public authorities may identify a specific problem for which a technical solution seems feasible, and they contract a specific group of researchers to develop this solution. Of course, often, the same researchers who work in universities of government labs are engaged in competitive bids for government procured research projects, so that the two systems overlap in practice.

As David (1993, p. 32) notes, the procedures of procurement and patronage suffer from the problem of setting the prices right. How much should governments invest in research grants to universities, and how much should they be prepared to pay for a specific project undertaken to solve a predefined technical problem? These are questions that are difficult, if not impossible, to answer. The third P, Property rights, provides at least a theoretical way out of this problem, for a special class of technological knowledge.

A part of knowledge generated through research and development leads to possibilities for products and processes that have commercial value. With a system of property rights, i.e., a (temporary) legal monopoly granted to one firm, these goods can be supplied on the free market. Thus, a system of property rights leaves to the market to decide what a 'fair' price for technological knowledge embodied in a product or process is. The incentive problem is solved by legally excluding others than the inventor (or patent holder) from using the technical information. Thus the patent holder is enabled to make a profit on her research.

Obviously, there are also certain disadvantages to granting a monopoly. With 'normal' economic goods (i.e., rival and excludable goods), economic theory clearly shows that a market with many suppliers and many buyers produces more welfare than a market in which only one (monopoly) or a few (oligopoly) suppliers are active. Put in simple terms, monopoly firms charge too high prices from a societal point of view. This is why public governments often pursue an active anti-trust and pro-competition policy. The trade-off between the advantages of a monopoly provided by patents and the disadvantages is often discussed as the trade-off between static efficiency (stimulating competition) and dynamic efficiency (stimulating invention through patents) (see, e.g., Kamien and Schwartz, 1982). The trade-off also plays an important role in the tension between government policies aimed at science and technology and anti-trust policy. In the context of European integration, for example, strict 
rules have been set to technology policy in order to ensure that it does not intervene with competition policy. ${ }^{3}$

Besides the problem of monopolies charging a too high price, there are also a number of other disadvantages to the patent system. David (1993) discusses the so-called 'commonpool' problem. This refers to the notion that firms often compete for the same invention, which leads to so-called patent races, in which the winner typically takes all (see, e.g., Dasgupta and Stiglitz, 1980). The common pool problem presents two problems from the point of view of social benefits and costs. According to David (1993), first, "it is likely that from the viewpoint of society there will be too many contestants in the races for priority in discovery and invention. Those entering consider only what they individually stand to gain, and they do not take into account the effect of their participation on the expected outcomes of all the other competitors" (p. 33). These effects on the outcomes of other contestants are obviously negative, for the more competitors there are, the smaller the probability for each of them to be first. In other words, when potential inventors fish a common pool of knowledge, resources will be spent in a wasteful way (from the point of view of the total economy). Second, again citing David (1993), "there is a tendency for private rents to be dissipated in the scramble for the prize of priority and all that it would bring. The private value of arriving at a new finding a little sooner than the second-place contestant is likely to exceed greatly the benefit that society would derive from the slight advantage in the date of discovery" (p. 33).

Thus, although patents do not only entail positive effects on welfare, most economic treatments on the subject would conclude that overall, the benefits of a patent system are positive (e.g., van Dijk, 1994, Scherer and Ross, 1990). For example, Mazzoleni and Nelson (1998, p. 281) conclude "In some areas, patent rights certainly are economically and socially productive in generating invention, spreading technological knowledge, inducing innovation and commercialization, and providing some degree of order in the development of broad technological prospects. However, in many areas of technology this is not the case". This conclusion leaves, however, at least two issues to be resolved. First, whether patents (or IPRs in general) are efficient means of reaching their goal (stimulating invention and commercialization thereof), and second, whether anything can be said about the design of patents.

With regard to the first question, it has been argued that firms have alternative options for appropriating the return to R\&D investment, and that these alternative options are often used more than patents. Levin, Klevorick et al. (1987), in a survey among large firms in the U.S., and Arundel and Van de Paal (1995) for European large firms, found that secrecy, establishing a lead-time, an effective marketing campaign, and learning effects were measures of protecting knowledge that were considered to be more effective than patents by many (although not all) firms. Similar conclusions had been reached in earlier studies such as Taylor and Silberston (1973). Mazzoleni and Nelson (1998) argue that the above mentioned studies that arrive at the conclusion that patenting is often only a minor tool in appropriating knowledge are biased towards large firms. Many of the ways in which these

\footnotetext{
${ }^{3}$ Business research sponsored by the European Commission is limited to the so-called pre-competitive phase.
} 
large firms appropriate knowledge are closely related to their size (marketing budget, learning effects), and hence small firms may have to rely more on patents.

Important differences in this respect exist between industries, or the knowledge bases underlying and the institutions surrounding them. For example, in the pharmaceuticals sector, due in part to the fact that copying of chemical substances is very precise and rather cheap, and given that authorities request detailed information about the contents of medicines, patent protection is considered to be very important. In the electronics sector, short product life cycles often make patents relatively inefficient, although most of the larger electronic firms hold large patent portfolios. Thus, the so-called 'propensity to patent innovations' differs considerably between different industries.

With regard to the issue of the design of the patent system, economic analysis has mainly analyzed the question how an 'optimal' patent should be designed. An optimal patent is one that maximizes the welfare of the invention it concerns, or, in other words, one that strikes the best balance between the positive and negative effects of patents as outlined above. In this respect, the issues of patent length (duration of the monopoly right) and patent breadth (scope of protection) have been widely analyzed. ${ }^{4}$

Increasing the length of a patent obviously increases the amount of profits the inventor may draw from her invention, but it also increases the welfare losses due to monopoly power. Nordhaus (1969) was the first to address the issue of patent length in a formal setting. In his analysis, the optimal patent length depends on the price elasticity of demand, and the elasticity of the extent of technical improvements with regard to R\&D expenditures. With higher price elasticity of demand for the new product, the optimal patent length is shorter, because the high monopoly price implies a large welfare loss. If larger productivity increases are achieved with a given level of $\mathrm{R} \& \mathrm{D}$, the optimal length of the patent will also be shorter, because $R \& D$ is cheap, and hence the incentive does not need to be very large.

Following Klemperer (1990), the formal literature mostly considers the issue of patent breadth in a context of so-called horizontal product differentiation. ${ }^{5}$ In this approach, technological innovation is seen as a process that produces more variants of a consumption good. Because consumer tastes differ, each new variant creates its own demand, without fully capturing the market. ${ }^{6}$ A broad patent then captures a large part of the horizontally differentiated product space. As in the case of patent length, the optimal breadth depends on a number of model parameters, such as various elasticities. Van Dijk's (1994, p. 113) conclusion that "the exact conditions for choosing an imitation or improvement strategy are not particularly important because they depend on specific modeling assumptions" in a strict

\footnotetext{
${ }^{4}$ Van Dijk (1994) also uses the concept of height, which refers to the novelty requirements.

${ }^{5}$ With horizontal product differentiation, products are differentiated into variants that cannot be ranked in terms of some objective quality measure, but are nonetheless distinct (for example, the commodity fruits is horizontally differentiated into apples, oranges, etc.). With vertical product differentiation, product variants can be ranked according to quality, e.g., French wine has a higher quality than Norwegian wine. In the latter case, consumers will choose on the basis of quality-price ratios.

${ }^{6}$ In terms of the example in the previous footnote, some people will always prefer oranges over new (genetically engineered) variants of fruit.
} 
sense refers only to his own model of patent height and breadth, but strikes me as reasonably valid for the field as a whole.

\section{Patents and technology spillovers}

The technological knowledge that is described in a patent application, is not only useful to the patent applicant but also to other inventors in the same field. Although these other inventors are not allowed to use the patented knowledge in a product or process that will be used for economic purposes, the knowledge in a patent may still be useful to them in different ways. For example, this knowledge may give them new ideas for inventions. Also, the knowledge described in a patent often increases the general stock of knowledge in a field, such as would, for example, be the case if a patent describes that some technical procedure is possible to carry out. Also, some patent systems, such as the European one, require the patent applicant to reveal so-called non-claimable knowledge if this is relevant to the device or procedure described in the patent.

Thus, even if a patent precludes pure imitation of an invention, it does not rule out all externalities related to it. The patent provides the inventor with a monopoly that enables her to generate profits and hence provides an incentive for the research effort, but it leaves certain aspects of the technological knowledge to be exploited by others than the original inventor. How much is left to others to explore, and, thus, how much can be appropriated by the inventor, depends on the breadth of the patent.

The fact that patents, at least patents that are not too broad, leave open externalities, is an important distinction with other types of IPRs. For example, trademarks and, perhaps to a lesser extent, copyrights do not induce any externalities, or at least not to the same extent as patents do. When a firm takes out a trademark, it basically seeks protection for its marketing activities. Obviously, marketing does not carry the same amount of spillovers than research and development, although, in some cases, it might be a just as effective means of strategic advantage for a firm. Given the economic importance of spillovers (or externalities) that was underlined above, this clearly establishes the special importance of patents as compared to certain other types of IPRs. ${ }^{7}$ One could say that a patenting system has important bearing on the dynamic efficiency (growth potential) of an economy, while this is less obvious for other types of IPRs.

This also implies that the breadth of patents has important consequences for the growth potential of the economy. Usually, however, the models of optimal patent design, which were discussed shortly in the previous section, do not consider these dynamic effects. They are limited to the static welfare effects of patents, i.e., they compare the welfare costs and benefits of a patent without taking into account the effect a patent may have on future innovation (through spillovers). Important exceptions to this are Scotchmer (1991) and Scotchmer and Green (1990), as well as the less-formal, qualitative literature on patent

\footnotetext{
${ }^{7}$ Obviously, this does not mean that copyrights or trademarks are not important for the economy. There are good economic, legal and other reasons for the existence of these forms of IPRs.
} 
breadth. The latter branch of literature started with early contributions by Kitch (1977) and Beck (1981), while Mazzoleni and Nelson (1998) is a recent contribution.

Taking into account the spillover effect of patents on the productivity of future research, one is faced with a familiar trade-off. On the one hand, broader patents reduce spillovers to other firms than the inventor. Although in principle these spillovers could be 'internalized' by the patent holder, i.e., the beneficial effects on future invention could be captured by the patent holder, this internalization is unlikely to be complete. For example, in case of a 'general purpose technology', the scope of the firm that holds the patent is unlikely to cover the complete spectrum of possible applications of the spillovers, and/or transaction costs to licensing may be too high to allow efficient spread of the spillovers to other firms. Thus, broad patents are bad for spillovers, and, hence, bad for dynamic performance of the economy.

On the other hand, broader patents increase the (potential) pay-off to the patent holder, and hence the incentive for invention is increased. By increasing the number of inventions, obviously, also the amount of spillovers is increased. Whether broader patents increase or decrease the amount of knowledge available for spillovers thus depends on the various elasticities involved in this process.

How this trade-off turns out, and hence whether or not broad patents are good for dynamic performance of the economy, is hard to judge in a purely theoretical approach. Without an idea of the empirical facts, it is likely that such theory runs into the same problems as were signaled above for the 'static' models of patent breadth. The outcome depends on model parameters, and the models are too abstract to make empirical estimation of the parameters possible. Thus, case studies of specific sectors, technologies and countries are very useful with regard to the question of patent breadth.

For example, recent practical discussions in the field of IPRs focus on the scope of protection that should be offered on inventions in fields such as computer software, integrated circuits designs and biotechnology (life) (see, e.g., chapters 11-15 in Wallerstein, Mogee et al., 1993, as well as Van Wijk and Junne, 1993). The general tendency of the discussion has been to offer more extensive protection for these technological fields than was possible on the basis of the legal arrangements some years ago (when these technologies were just coming into existence).

Mazzoleni and Nelson (1998) warn against such a trend of broadening patent protection. They argue that when technological change proceeds in "cumulative systems" (p. 281), broad patents are potentially hampering to the rate of invention. The danger they see is that an early, broad patent in such a field locks out firms who do not have access to this patent, especially if transaction costs for licensing are high. In other words, although they do not use the term 'spillovers' or 'externalities', they make exactly the same argument against broad patents as has been made above using the idea of spillovers. Merges and Nelson (1990) discuss a number of specific examples from the (recent) history of technology to support the case that broad patents hinder spillovers, due to, among other things, high transaction costs for licensing. 
I tend to support the Mazzoleni and Nelson conclusion that broad patents are potentially dangerous. There is no need to use the patent system to aim to internalize all the spillovers of invention to a single firm (i.e., the inventor). This would essentially come down to eliminating a large part of the potential benefits to the economy at large, because no single firm is large enough to fully exhaust the possibilities of important inventions in key technology fields. The aim of a patent should be to provide a firm with the possibility to make a fair profit in order to earn back its $R \& D$ costs. It is therefore perfectly sound to leave a large part of the spillovers to outsiders, and thereby increase the overall benefits to the economy. As was argued in Section 2, this is the basic idea behind modern growth theory, a part of which argues that without such spillovers, long-run growth would converge to zero.

In many respects, the studies by Mazzoleni and Nelson (1998) and Merges and Nelson (1990) reach conclusions opposite to those in the early contributions by Kitch (1977) and Beck (1981). These authors were arguing in favour of broad patents, essentially to rule out inefficiencies in the coordination between many contestants in a patent race following an early basic patent in a field. They recommend that such an early basic patent should be broad, so that the firm that holds it may either explore the field on its own, or license the patent to the other firms that are most promising with regard to success in R\&D.

The World Bank (1998), finally, although it argues in general terms for increasing the breadth of patents on a worldwide scale (the so-called TRIPs agreement, see my other paper for this conference for more details), warns against too broad protection in the specific field of gene splicing, on the account that this is a technology with such a broad range of applications, that patents run the risk of locking out too much spillovers.

\section{Conclusions and summary}

The economic function of patents is to protect inventors from being imitated, and hence to provide them with an incentive to perform research and development, and to commercialize the inventions that stem from it. Patents are one particular way of solving the problem of market failure that arises because technological knowledge is, to a certain extent, a so-called public good.

Patents grant their holder a monopoly right to apply or sell a product or process for a limited period of time. Besides the positive impact of this monopoly on the incentive for invention, there are also certain negative aspects of such a monopoly. These are mainly related to the fact that, from a societal point of view, a monopolist producer charges too high prices for its product, and this causes welfare loss for consumers.

Patents also have an impact on the future rate of invention, because they generate so-called spillovers as a by-product of the invention process. Examples of spillovers are when an invention generates an idea (possibly in somebody else's brain) for a new invention. Such spillover effects are especially valuable from an economic point of view, because they are an important impetus to economic growth.

Microeconomic models analyze the beneficial aspects of patents and compare them to the welfare losses implied by the monopoly. In this way, an 'optimal' design of the patent 
system, in terms of the duration (length) of a patent and the scope of protection (breadth) can be determined. However, these models have two main advantages. First, they do not generally consider the dynamic aspects of patents, i.e., they do not take into account the impact of technology spillovers on the future rate of invention (exceptions to this tendency have been mentioned above). Second, the models are usually so abstract that their practical implications are weak.

Reviewing some of the recent more qualitative literature on patent breadth, the paper arrived at the conclusion that when technological spillovers are strong, broad patents may be potentially hampering for the future rate of invention. In some fields of new technology, such as genetics, the danger of too broad patents seems to be very real.

The final, admittedly somewhat paradoxical, message of the paper is therefore that patents are of crucial importance to economic growth, but that, especially in fields where spillovers are strong, patents should not be very broad.

\section{References}

Arundel, A. and G. Van de Paal (1995). Innovation Strategies of Europe's Largest Industrial Firms. Maastricht, MERIT, unpublished manuscript.

Beck, R. L. (1981). "Competition for patent monopolies." Research in law and economics 3: 91-110.

Dasgupta, P. and J. E. Stiglitz (1980). "Uncertainty, industrial structure and the speed of R\&D.” Bell Journal of Economics 11: 1-28.

David, P. A. (1993). Intellectual Property Institutions and the Panda's Thumb: Patents, Copyrights, and Trade Secrets in Economic Theory and History. Global Dimensions of Intellectual Property Rights in Science and Technology. M. B. Wallerstein, M. E. Mogee and R. A. Schoen. Washington, D.C., National Academy Press: 19-64.

Freeman, C. and L. Soete (1997). The Economics of Industrial Innovation. 3rd Edition. London and Washington, Pinter.

Grossman, G. M. and E. Helpman (1991). Innovation and Growth in the Global Economy. Cambridge MA, MIT Press.

Jones, C. (1995). "R\&D based models of economic growth." Journal of Political Economy 103: 759-784.

Kamien, M. I. and N. L. Schwartz (1982). Market Structure and Innovation. Cambridge, Cambridge University Press.

Kitch, E. W. (1977). "The nature and function of the patent system." Journal of law and economics 20: 265-290.

Klemperer, P. (1990). "How broad should the scope of patent protection be?" RAND Journal of Economics 21: 113-130.

Landes, D. (1969). The unbound Prometheus: Technological Change 1750 to the present. Cambridge, Cambridge University Press. 
Levin, R. C., A. K. Klevorick, et al. (1987). "Appropriating the Returns from Industrial Research and Development." Brookings Papers on Economic Activity 3: 783-820.

Maddison, A. (1991). Dynamic Forces in Capitalist Development. A Long-Run Comparative View. Oxford, Oxford University Press.

Marshall, A. (1890). Principles of Economics. London.

Marx, K. (1981). Capital. Vol. 3. Harmondsworth, Penguin.

Mazzoleni, R. and R. R. Nelson (1998). "The benefits and costs of strong patent protection: a contribution to the current debate." Research Policy 27: 273-284.

Merges, R. P. and R. R. Nelson (1990). "On the complex economies of patent scope." Columbia Law Review 90: 839-916.

Nordhaus, W. D. (1969). Invention, Growth and Welfare. A Theoretical Treatment of Technological Change. Cambridge MA, MIT Press.

Romer, P. (1986). "Increasing Returns and Long Run Growth.” Journal of Political Economy 94: 1002-1037.

Scherer, F. M. and D. Ross (1990). Industrial Market Structure and Economic Performance. Boston, Houghton Mifflin Company.

Schumpeter, J. A. (1939). Business Cycles: A theoretical, historical and statistical analysis of the capitalist process. New York, McGraw-Hill.

Scotchmer, S. (1991). "Standing on the shoulders of giants: Cumulative research and the patent law." Journal of Economic Perspectives 5: 29-41.

Scotchmer, S. and J. Green (1990). "Novelty and disclosure in patent law." RAND Journal of Economics 21: 131-146.

Solow, R. M. (1956). "A Contribution to the Theory of Economic Growth." Quarterly Journal of Economics 70: 65-94.

Taylor, C. and A. Silberston (1973). The Economic Impact of the Patent System. Cambridge, Cambridge University Press.

Van Dijk, T. (1994). The Limits of Patent Protection. Essays on the Economics of Intellectual Property Rights. Ph.D thesis Faculty of Economics. Maastricht, University of Limburg.

Van Wijk, J. and G. Junne (1993). Intellectual Property Protection of Advanced Technology. Changes in the Global Technology System: Implications and Options for Developing Countries. Maastricht, UNU/Intech.

Wallerstein, M. B., M. E. Mogee, et al., Eds. (1993). Global Dimensions of Intellectual Property Rights in Science and Technology. Global Dimensions of Intellectual Property Rights in Science and Technology. Washington, D.C., National Academy Press.

World Bank (1998). World Development Report. Knowledge for Development. 1998/1999. Oxford, Oxford University Press. 


\title{
The Role of Intellectual Property Rights in TECHNOLOGY TRANSFER
}

\author{
by Bart Verspagen* \\ (ECIS, Eindhoven University of Technology, and MERIT, Maastricht University) \\ Paper for the WIPO Arab Regional Symposium on the Economic Importance of Intellectual \\ Property Rights, Muscat, Sultanate of Oman, February 22-24, 1999.
}

First draft, February 1999

\section{Introduction}

The role of knowledge in the process of economic development can hardly be underestimated. The economic history of the world shows that, in the long run, only by applying new production techniques and introducing new products, the level of welfare can be increased. The development of such new processes and new products is a goal that is actively pursued by both governments and private firms.

Research on the relation between science and technology investment on the one hand and economic growth and development on the other hand, clearly shows that it is not only the amount of resources that are invested that counts, but also the institutional arrangements under which this investment takes place. One specific type of institutional arrangement that is of great importance is that of intellectual property rights (IPRs).

This paper intends to outline some of the issues on the relationship between IPRs and technology transfer from developed countries to developing countries as a way of development. This is vast area of research that has especially flourished in the last decade or so. A comprehensive coverage of the area would require far more space and efforts than were available for this paper. Hence, what will be attempted here is to present a short overview of some of the theoretical and practical developments in the field, and use this overview to discuss a number of options for future research and debate. In doing this, the perspective used is that of an economist, for the obvious reason that this is my field of work. Other disciplines, most obviously legal studies, have a lot to say on the topic, but I cannot pretend to be able to do justice to them. Therefore, stimulation of thinking and constructive debate is my aim rather than a final statement or even a complete overview of issues.

In making my points, I will largely focus on patents as the form of IPRs that are most relevant to technological change. I will thus mostly leave aside other forms of IPRs, although these may be important for developing countries in specific instances. Also, I will not discuss

\footnotetext{
* Eindhoven University of Technology, PO Box 513 DG 1.21, 5600 MB Eindhoven, Netherlands. Tel +3140 2475613, fax +31 40 2474646. MERIT, PO Box 616, 6200 MD Maastricht, Netherlands. Tel +31 433883869 , fax +3143 3216518. Email: bart.verspagen@ merit.unimaas.nl, web: http://meritbbs.unimaas.nl/verspagen.html
} 
recent changes in patent regimes that are the result of the appearance of new technologies (e.g., issues of patentability of life or computer programs).

The rest of this paper is organized as follows. Section 2 provides a short overview of the economic reasoning on the role of institutions in economic growth and development, leading to the underlining of the importance of IPRs. Section 3 provides an overview of the main factors through which IPRs have an impact on development and technology transfer. This section also outlines the main developments at a practical level, i.e., how international IPR regimes converged into the so-called TRIPs agreement that has been in effect since 1996. Section 4 introduces three main points for discussion, by drawing on different parts of the economic literature. Some specific recommendations will be made with regard to supportive policies in the field of international IPRs. Finally, Section 5 summarizes the main conclusions.

\section{The role of institutions in economic growth and development}

In the 1950s, the theory of economic growth became dominated by the so-called neoclassical model (Solow, 1956). This model argued that economic growth in a country can be solely explained by the accumulation of capital, the (exogenous) growth rate of the labour force, and exogenous technical progress. Solow (1957), following a method developed earlier by Tinbergen (1943), presented calculations on the contribution of technical progress. Solow concluded that $88 \%$ of the U.S. growth rate over 1909-1949 was due to technical progress.

With hindsight, the two Solow papers can be viewed as the start of an era in which economic growth was analyzed mostly in a purely quantitative way. The work by economists focused on those factors in economic growth that can be related to measurable phenomena. Thus, much work was aimed at refining the measurement of labour input (e.g., by taking into account education, or human capital), measuring capital in a better way, or proxying the impact of technical progress by variables such as R\&D expenditures. ${ }^{8}$

Although such a purely quantitative approach goes a long way in explaining differences in economic growth between nations, it leaves certain important empirical phenomena without explanation. Most specifically, one can point to a number of historical cases where two different (groups of) countries seemed to be in more or less identical circumstances (i.e., more or less equal values for 'measurable' variables), but still showed widely different behaviour in terms of economic growth. De Long (1988) discusses a number of such cases, with Argentina versus Western European countries such as Austria at the beginning of the century as a prime example of uneven growth. Freeman (1994) discusses the world of differences between Latin-American and South-East Asian growth as another example.

Such examples, in the course of the 1980s and 1990s, led to a (renewed) view on economic growth in which non-measurable factors were given a much more important role. Freeman (1994) and Abramovitz (1994) are examples of this line of thought. Many of these factors are discussed under the heading of 'institutions'. North (1990) defines institutions as 
"the rules of the game in a society, or, more formally, [..] the humanly devised constraints that shape human interaction" (p. 3). In addition to formal rules (i.e., laws), North also considers informal rules (codes of conduct as embodied in 'culture') as a part of institutions. Recognition of the important role that institutions play in economic growth and development came with the award of the Nobel Prize in economics to Douglas North, who is considered as one of the great proponents of the economic theory on institutions. ${ }^{9}$

Abramovitz (1979) uses the term 'social capability' as a broad description of the set of institutions that facilitate the international diffusion of technological knowledge to less developed countries. Among the factors that he considers of prime importance for 'social capability' are the educational system, and the financial system (banking). Education has a direct bearing on the quality of the labour force in a country, and is thus of crucial importance in the ability of a country's productive system to assimilate technology from abroad.

Intellectual Property Rights (IPRs) are another important factor in the debate on the role of institutions in technology transfer (Yankey, 1987, Van Wijk and Junne, 1993). IPRs are the part of legal institutions that connects most closely to the process of technology itself, and they are considered to be necessary to provide incentives for the production of new technology by private firms operating in a market economy. The history of IPRs dates back to the pre-industrial era (see, e.g., David, 1993), so that all the technological developments that took place since the first Industrial Revolution were indeed shaped by the various IPR regimes in place in various countries throughout history. The next section discusses the role of IPRs in development in more detail.

\section{Patents and technology transfer: a short review of the debate}

Patents are the form of intellectual property rights associated with technological inventions. The main aim of a patent system is twofold: first to protect an inventor from imitation, and hence to increase the incentive for inventive activity, and, second, to stimulate the dissemination of technical information, so that it can be used in further inventive activity, thereby increasing the system-wide rate of invention. The first of these two aims is wellknown, while the second is less often quoted in (popular) debates about the patent system. The first aim (incentive for invention) stems from the fact that imitating an invention is often much less costly than inventing, so that a fast-moving imitator might sell a new product (in the case of a product innovation) cheaper than the innovator can. Hence, without patent protection, innovation might not lead to profits, and thus a firm operating in the market will lack the incentive to invest in inventive activity $(\mathrm{R} \& \mathrm{D}) .{ }^{10}$

The second aim stems from the important notion of externalities. In economic theory, an externality arises when the social costs (in case of a negative externality) or benefits (in case

\footnotetext{
${ }^{8}$ A few of the most well-known references in this tradition are: Jorgenson and Griliches (1967), Griliches (1979), Maddison (1987), Denison (1966).

${ }^{9}$ North (1990), North and Thomas (1973).

${ }^{10}$ Note that there are also other forms of protecting inventive information, such as secrecy (especially important for process innovations), and lead-time. These other options are discussed in more detail in my other paper for this conference.
} 
of a positive externality) are larger than the private costs. In the example of innovation, the private benefits of an innovation to the innovator are the increased profits that result from it. The wider concept of social benefits also includes (for example) the notion that the innovation increases the stock of general knowledge, and hence increase the effectiveness of research by other inventors. Thus, even if these other inventors are not allowed to copy the patented knowledge, they may derive from it important new information that leads to new inventions. By requiring the applicant for a patent to disclose the technical information on which the patent is based, the patent system aims not only to stimulate the generation of externalities, but also to increase their accessibility.

Note that these two aims are somewhat in tension with each other. By increasing the scope of patent protection one may increase the incentive for invention because imitation is made more difficult, and hence the innovator may capture profits from a broader range of potential applications. However, at the same time, this decreases the potential benefits of other inventors (externalities). This trade-off plays an important role in the debate on patent protection and technology transfer, which will now be outlined.

By technology transfer, this paper will refer to the process in which technological knowledge developed and (first) applied in the developed countries (say, OECD countries) is transferred to countries with lower levels of technological knowledge (as embodied in their productive process). It has to be recognized that the latter set of countries is in fact a very heterogeneous group, including, for example, the so-called Newly Industrialized Countries (NICs), as well as countries with pre-industrial agricultural economies.

Broadly speaking, the literature discerns four different ways in which patents have an impact on development and/or technology transfer (e.g., Yankey, 1987, Van Wijk and Junne, 1993).

1. Strong(er) patent protection in developing nations may increase the inventive efforts in the developing countries themselves, and thereby increase the rate of growth in these countries.

2. Patents allow for (international) licensing, so that firms in developing countries may buy technology from firms in (technologically) more advanced nations (technology transfer).

3. Strong(er) patent protection may be necessary to induce firms from developed countries to engage in one of many different economic transactions that may lead to technology transfer. One may think of Foreign Direct Investment (FDI), exports (to developing nations) of capital goods embodying technological knowledge, joint ventures between firms in developing and developed countries, etc. Without some form of protection of their knowledge in the foreign markets, firms from developed nations may choose not to engage in these activities, because they run the risk of their knowledge being copied.

4. Developing nations that do not provide a system for protection of intellectual property of imported technology run the risk of retaliation in terms of trade restrictions. Especially the U.S. government has (recently) been active to enforce 
protection of intellectual property of U.S. firms by means of trade measures (Van Wijk and Junne, 1993).

All of these reasons are not only subject to academic debate by theorists, they were and are also subject of intense negotiations in international organizations such as the World Intellectual Property Organization (WIPO) and the World Trade Organization (WTO) (see, e.g., Mody, 1990, Van Wijk and Junne, 1993, and World Bank, 1998). Van Wijk and Junne (1993) describe how in the 1960s and 1970s, the large majority of developing countries began to oppose the implementation of a (strong) patent system in their own economies:

“D eveloping countries did not deny that industrial property systems could encourage industrialization, but contended that in developing countries, due to the weak economic and technological structures, they did not bring the desired benefits. It was argued that in developing countries the privileges created by the industrial property systems failed both to stimulate inventions among their own nationals and did not encourage the rapid transfer, appropriate adaptation or widespread diffusion of imported technology" (p. 22).

Thus, the argument was twofold: first that the technological capabilities of firms in developing countries were too low to generate important new innovations (point 1 above), despite the existence of a patent system, and, second, that the desired technology transfer (points 2-4 above) did not materialize. In 1975, UNCTAD published a study (UNCTAD, 1975) that presented a lot of evidence in favour of this position. For example, the report outlined statistical trends illustrating the marginal role of developing countries in total patents granted in the world. Moreover, it showed that in developing countries, the large majority (typically, more than three quarters) of patents granted was controlled by foreign firms (from the developed world).

The argument that developing countries can hardly contribute to the advancement of the technological frontier remains valid even today. This is related to the limited amount of resources available in these countries, in terms of human capital, funds to be invested in frontier research, and cumulated experience in research. Corporate $R \& D$, and hence patenting, is a matter of the developed nations, and within them, mostly of the five or so largest countries (European Commission, 1998). Thus, without policy measures aimed to increasing the indigenous research capabilities of developing countries, a patent system can hardly be expected to be an efficient means of stimulating innovations in the poorer parts of the world.

The role of licensing (factor 2 above) was also shown to be important only for a limited set of countries. In order to use licensed knowledge effectively, firms in developing countries need a certain level of technological sophistication of their own. Analogous to the point of indigenous research capabilities raised above, this is exactly what was often lacking, due to shortages of human capital etc. Some even went so far as to suggest compulsory licensing as a means to effectuate technology transfer, but this is extremely difficult, because mere 
licensing without the transfer of (tacit) know how from the side of the patent holder can not be expected to be efficient (Yankey, 1987). The ineffectiveness of compulsory licensing is also shown by the limited number of cases of such arrangements (typically less than 5 per country over the period of a decade, see Yankey, 1987, table 2.1).

In practice, one observes that only certain countries are able to use technology licensing as an effective way of (inward) technology transfer. Typically, in these cases, technology licensing goes hand in hand with the build-up of domestic technological capabilities. Freeman (1994) discusses the case of the Korean firm Samsung, which effectively used licensing agreements with various Western European and U.S. companies to build-up its own technological capability. Over time, Freeman observed a rapid tendency for Samsung to switch from reliance on licensing agreements to develops its own frontier technology. In fact, taking R\&D intensity and patenting as indicators, Korea, as well as other South-East Asian NICs can be seen to converge rapidly to the technology frontier in the course of the 1990s (e.g., European Commission, 1998, for recent data, and Soete and Verspagen, 1993, for a theoretical and empirical analysis). In general terms, the conclusion seems justified that technology licensing may be a useful part of a policy aimed at building up local technology capabilities, but it is only a part of such a policy.

Based on the arguments on the role of patenting in developing countries, a political discussion took place in the 1970s and 1980s between developing countries and developed nations, in which the issue of patent protection in developing nations was heavily debated. In broad terms, the developing nations argued for less strong patent protection in their own economies, while the developed world called for global strengthening of patent protection. Van Wijk and Junne (1993) provide an overview of this debate, as well as some of the finer (legal) details as they were discussed at various conferences organized by WIPO. They also describe how, at the end of the 1980s, the developed nations started to pull away this debate from WIPO, trying to integrate the issue of intellectual property rights with issues of free trade. In practical terms, this meant that negotiations about intellectual property rights were integrated into the Uruguay Round. This implied that negotiations about free trade were coupled with negotiations on IPRs, leading eventually to the so-called Trade Related aspects of Intellectual Property (TRIPs) agreement.

The TRIPs agreement is a part of the WTO, and sets minimum levels of intellectual property protection for the whole range of forms of IPRs (patents, copyrights, trademarks, industrial designs, etc.). It also requires signatories to establish certain basic legal measures to prevent infringement. Disputes over TRIPs are subject to the same settlement procedures as WTO in general. TRIPs became effective in 1996, but developing countries are granted several transition periods applying to specific parts of the agreement, so that it will become fully effective only in 2006.

The TRIPs agreement means that countries that do not respect the minimum levels of IPRs set can now expect retaliation measures in terms of trade restrictions (point 4 above). Van Wijk and Junne (1993) point out that this is an especially effective measure in combination with the trend found in many developing countries to switch from a policy of import substitution to export-led growth. Obviously, export-led growth crucially depends on access 
to world markets, and hence the pressure to respect the IPR levels set by TRIPs becomes larger.

Thus, in the late 1990s, the debate on the role of patents in technology transfer mainly focuses on points 3 and 4 of the above list. The first two points, i.e., the (direct) impact of a patent system on domestic inventive activity in developing nations, as well as the issue of technology licensing, were shown to depend crucially on domestic technological capabilities. These can only be built up by means of a broad policy which includes, besides IPRs, also elements such as (semi-)public research facilities, education and training of the labour force, and industrial and trade policies.

With the TRIPs agreement in effect, the consensus on the issue of IPRs and technology transfer seems indeed to converge to the points 3 and 4 listed above. The uniform and strong IPRs are generally considered to stimulate technology transfer by means of FDI, joint ventures and by stimulating international trade in general. Mansfield (1993), Mansfield (1994), Mansfield (1995) provides some empirical evidence for this assumed relationship.

The first two of these papers by Mansfield analyzes survey data obtained for 100 U.S. firms in a range of industries. About half of the firms in this sample reported that strength or weakness of IPRs has a strong effect on whether or not direct investment will be made. This effect was found to be strongest in the chemicals and electrical equipment sectors, and to apply mostly to investment related to $R \& D$ facilities and facilities to manufacture complete products. The top countries that were reported as having too weak IPRs to permit investment in joint ventures with local partners, were India (44\% of respondents indicate IPRs are too weak), Nigeria (33\%), Brazil (32\%), Thailand (31\%), Indonesia and Taiwan (28\%). The same countries were reported to have IPRs too weak to permit transfer of the newest or most effective technology to wholly owned subsidiaries, or to permit licensing of the newest or most effective technology. Mansfield (1995) extends the survey to Japanese and German firms, and also undertakes more sophisticated econometric testing. The findings, again, show that weak IPRs may be an important barrier to technology transfer.

The World Bank, in its World Development Report 1998/99, also champions strong and uniform IPRs as in the TRIPs agreement. Their empirical evidence mainly consists of the Mansfield surveys mentioned above. Despite this apparent consensus, the academic debate on the issue TRIPs is far from conclusive. Siebeck (1990) concluded that the theory did not provide any strong answers on how strong IPRs in developing countries should be, and that the empirical studies on the issue were too few to allow firm conclusions. In 1992, a conference was convened at the National Academy of Sciences in the U.S., which debated the issues. In the proceedings, which were published as Wallerstein, Mogee et al. (1993), no firm conclusion was reached on whether a uniform system of strong IPRs was to be preferred over a system with international differentiation in IPRs. ${ }^{11}$ Since then, although the first of these two variants now seems the de facto situation since TRIPs came into effect, the theoretical debate has not supplied the final answer, as will be argued in the next section.

\footnotetext{
${ }^{11}$ See, e.g., the contributed chapters by Sherwood (1993) and Frischtak (1993).
} 


\section{Discussion and issues for further research}

The debate that was briefly outlined in the previous section is still largely unresolved, and more theoretical and empirical research is necessary to arrive at useful conclusions. This section will attempt to outline three angles from which further contributions to the debate may be made. These three points are all somewhat preliminary, and must be considered as starting points for further research and debate, rather than finalized and testable propositions.

The first issue relates to the question of whether a patent regime with (more or less) uniform protection levels is desirable from a point of view of total world welfare (see Sherwood, 1993, Frischtak, 1993). In microeconomic theory, the length and breadth of patents have been analyzed. ${ }^{12}$ The length of a patent refers to its duration, while the breadth refers to the scope of protection. ${ }^{13}$ Nordhaus (1969) analyzed the 'optimal' patent length, and concluded that this depends on variables such as the price elasticity of product demand, and the elasticity of the extent of technical improvements with regard to R\&D expenditures.

Following Klemperer (1990), the literature mostly considers the issue of patent breadth in a context of so-called horizontal product differentiation. ${ }^{14}$ In this approach, technological innovation is seen as a process that produces more variants of a consumption good. Because consumer tastes differ, each new variant creates its own demand, without fully capturing the market. ${ }^{15}$ A broad patent then captures a large part of the horizontally differentiated product space.

Van Dijk (1994, chapter 7) presents a model in which two countries, which trade with each other, choose the optimal level of patent breadth. He arrives at the following conclusions:

"[W]hen countries place equal weight on profits and consumers' surplus of their own citizens (... ) patent breadths are too narrow. This result reflects the existence of a positive externality flowing from each country's patent breadth to the profit and consumers' surplus enjoyed by citizens of the other country. (... ) [E]xcept in very special circumstances, equilibrium patent breadths are not identical in the two countries. (... ) Further, if equilibrium breadths are sufficiently asymmetric, there is no symmetric patent policy that Pareto-dominates the original equilibrium" (p. 1534).

\footnotetext{
${ }^{12}$ My other paper for this conference will consider these issues in somewhat more detail. Here, I only focus on the issue of an international patent system.

${ }^{13}$ Van Dijk (1994) also uses the concept of height, which refers to the novelty requirements.

${ }^{14}$ With horizontal product differentiation, products are differentiated into variants that cannot be ranked in terms of some objective quality measure, but are nonetheless distinct (for example, the commodity fruits is horizontally differentiated into apples, oranges, etc.). With vertical product differentiation, product variants can be ranked according to quality, e.g., French wine has a higher quality than Norwegian wine. In the latter case, consumers will choose on the basis of quality-price ratios.

${ }^{15}$ In terms of the example in the previous footnote, some people will always prefer oranges over new (genetically engineered) variants of fruit.
} 
In practical terms, these results establish two main points. First, in an international context, spillovers between countries are relevant decision variables in designing national regimes of intellectual property rights. More specifically, national governments may want to set the scope of protection at a broader level than they would if they based their policy just on national considerations. Second, there is not much theoretical support for the preference of a uniform worldwide level of patent protection (breadth) over a system with differentiated patent breadth. Third, international coordination of the scope of patent protection (breadth) does not necessarily lead to unequivocally 'better' results than a regime in which each country sets its patent policy independently of the rest of the world. ${ }^{16}$ In fact, in discussing his results, Van Dijk makes the following, quite strong, statement:

"In terms of our model, one could say that the north has a high and the south has a low innovation density. The model predicts that asymmetric innovation densities lead to extensive patent protection in the innovation-intensive region and narrow protection in the weaker region. This situation can indeed be observed in the world (... ). The proposal of northern countries, however, to extend their standards of protection to the south does not Pareto-improve the global welfare if innovation densities are too different (as they seem to be)." (p. 154-5).

Obviously, Van Dijk's model is but one in a large literature in this field. Other models of the role of international property rights regimes and international trade are, for example, Deardorff (1992), Diwan and Rodrik (1991), Helpman (1993) and Chin and Grossman (1990). All of these models are highly stylized theoretical constructs, for which one needs a great deal of imagination to apply them to practical situations. ${ }^{17}$ Other models, such as the one by Deardorff (1991) and the one by Diwan and Rodrik (1991) are more positive towards the idea of strengthening global patent protection. ${ }^{18}$ All in all, the conclusion reached by Primo Braga (1990), namely that economic theory does not provide a clear-cut answer to many questions in relation to technology transfer and intellectual property rights, still seems to be valid.

Nevertheless, one may draw some positive conclusions from the theoretical debate, despite its high level of abstraction and relative indeterminancy. Even though some of the studies quoted above are critical towards the implications of, for example, the TRIPs agreement, there is no where near enough empirical or theoretical evidence to justify a campaign against

\footnotetext{
${ }^{16}$ In the latter conclusion, the concept of 'Pareto-optimality' plays a large role in Van Dijk's analysis. This concept refers to the notion that it is difficult to weight individuals' welfare level. A so-called Paretoimprovement is one in which all individuals in the economy at least have the same level of welfare as before the improvement, and at least one individual has a higher level of welfare. Note that this is a rather strong requirement, because one may imagine situations in which a part of welfare of a (small) group of individuals is 'sacrificed' for a larger improvement in the welfare of another (larger) group.

${ }^{17}$ See David (1993) for a general discussion of the difficulties of applying economic theory to the practice of intellectual property rights.

${ }^{18} \mathrm{I}$ am afraid this is one of those situations where the (ironic) saying applies that one can always find an economist to defend one's position, no matter how outrageous this position is.
} 
TRIPs. (Also, of course, such a campaign would not have any realistic hopes of success). Whether or not the uniform and strong IPRs in TRIPs will prove beneficial will be a matter that may ultimately be solved by ex post empirical research. In the mean time, however, it is clear that supportive measures in terms of technological capacity building may greatly increase the efficiency of technology transfer, and thus, in a way, make the TRIPs agreement more efficient.

The debate of the 1970s and 19870s already clearly showed that in order for (strong) IPRs to be effective in developing countries, the domestic capability of these countries to generate and use new technologies needs to be enhanced (see above). Relatedly, the model by Van Dijk cited above points to the fact that a regime with uniform and strong worldwide IPRs may be more efficient (in terms of welfare) when differences between countries in terms of technological capabilities are small. The World Bank, in its most recent World Development Report, also points to the importance of building local knowledge bases. Thus, I would argue that TRIPs is not to be considered as the final solution to problems of technology transfer and development, but rather as a most useful step in awareness of the importance of IPRs and technology in general. In addition to agreements of IPRs, the developed and developing world should continue to focus on building up domestic technological capabilities in developing countries. IPRs play an important role in this process, but there is more to it than just IPRs.

What role could international organizations such as the World Bank, WIPO and WTO play in this process? WTO, although it is the platform at which TRIPs was negotiated, and at which conflicts on TRIPs must be submitted, does not seem to be a candidate for such a role. Its nature as a body to enhance free trade does not conform to policy goals that concern domestic issues, such as the stimulation of R\&D infrastructure. The World Bank obviously has a task in this area, and the World Development Report contains many examples of how this organization attempts to help build up local knowledge infrastructures.

Whether or not WIPO may play a role in this process, for me, is a matter open to debate. On the one hand, one may argue that WIPO is an international platform, much like WTO, which should not 'intervene' in local issues. On the other hand, as history has shown, the issue of international IPRs, which is, of course, the main concern of WIPO, is indeed closely related to domestic technology capabilities. As I have tried to argue here, the new institutional environment (TRIPs) adds another dimension to this issue, rather than making it obsolete. Thus, given the increased need for international attention to technology capacity building in developing countries, one may imagine that WIPO would, in some way, address this issue. One may think, in first instance, of initiating research aimed at clarifying some of the issues that are still clouded, as this brief summary of the literature showed.

The second issue that I want to address in this section, in a way builds on the first one, because it considers the issue of patent breadth. In the econometric literature on international R\&D spillovers, one of the 'hot issues' is the question whether or not such spillovers are embodied in traded goods and/or FDI. Coe, Helpman et al. (1997) have forcefully argued that R\&D spillovers are indeed embodied in trade goods, while Lichtenberg and Van Pottelsberghe (1996) found that R\&D spillovers are connected to FDI flows between 
countries. These papers do not investigate the causal effect between embodied (either in trade or FDI) spillovers and IPRs. Thus, a first line of research that may prove useful to the debate outlined in the previous section could be to incorporate IPRs in such spillovers models.

However, Fagerberg and Verspagen (1998) also introduce into these models so-called disembodied spillovers. They follow earlier work by among others Cornwall (1977) and Abramovitz (1979) in relating these disembodied spillovers to the initial level of labour productivity in an industry. An estimated negative sign on this variable is interpreted as evidence of the hypothesis that relatively backward countries benefit from the international diffusion of technology. Because a variable taking into account trade-embodied R\&D spillovers à la Coe, Helpman et al. is also present in the Fagerberg and Verspagen model, the effect related to initial labour productivity is interpreted as disembodied spillovers.

Fagerberg and Verspagen find that in a sample of 14 OECD countries for the period 19751995, disembodied spillovers have a much stronger impact on productivity growth than tradeembodied spillovers. In other words, the international diffusion of technology mainly takes place through other channels than international trade in goods. Admittedly, Fagerberg and Verspagen do not consider the effects of FDI embodied spillovers. Still, their results seem to underline the crucial importance of spillovers through other channels than embodiment (think of international mobility of labour, international contacts at conferences, scientific and technical literature, patent specifications, etc.).

One important caveat must be placed with regard to the application of these results to the relationship between technology transfer and patents. Verspagen (1991), in an empirical model that did not include any type of embodied spillovers, found that disembodied spillovers of the type that Fagerberg and Verspagen estimate, tend to decrease with the level of the technology gap between two countries. In other words, for countries lagging far behind the world technological frontier, 'technological congruence' (Abramovitz, 1979) may be too low to allow them to benefit from disembodied spillovers. Thus, the results that Fagerberg and Verspagen find may indeed be rather specific to the set of countries included in their analysis.

Although much more research is necessary to extend the Fagerberg and Verspagen results to the issue of North-South technology transfer (e.g., extending the set of countries in the analysis, as well as taking into account FDI), the results do seem to point out that, to a certain extent, free riding on foreign knowledge is possible. Whether or not such a process involves substantial infringement on patent holders' rights is not clear from the Fagerberg and Verspagen analysis. However, it is well imaginable that by increasing the patent breadth, especially in those countries benefiting from the spillovers, i.e., the developing countries, reduces the scope for such disembodied spillovers. At the same time, according to the arguments set out in the previous section, such stronger IPRs may stimulate trade and FDI, and thereby increase technology transfer related to these factors. Whether or not the net effect on the amount of spillovers taking place is positive or negative is highly speculative given the current state of the art in this field of research.

The third and final issue that I would like to raise in this section concerns the topic of appropriate technology. As is well-known from the development literature, not all 
technologies developed in OECD countries can readily be used in developing countries. Many of these technologies, or at least their specific implementation, are specific to the (advanced) needs of the societies they are developed in, or depend on infrastructures that are not commonly found in many of the developing countries. Abramovitz (1994) has termed this 'a lack of technological congruence'.

This implies that not all R\&D efforts by firms in OECD countries are relevant for the issue of technology transfer. In general, it is quite difficult to make a clear-cut distinction between sectors with more or less appropriate technology. For example, although much of the research in the electronics sector is obviously beyond the reach of many developing economies, the relatively high-tech field of mobile telephony is a well-known example of a field where diffusion potential is large in many developing countries, due to a low level of commitment to an installed base of wired communication.

However, one field for which the outcomes of R\&D carried out in OECD countries clearly have large consequences for developing nations, is biotechnology (see, e.g., Acharya (1995) and Van Wijk and Junne, 1993). The impact of biotechnology on developing countries is a vast area of research in which I cannot claim any expertise, but I would nevertheless like to conclude this paper with a few observations on this field.

The first observation I would like to make is that in a field where the economic relevance of a technology is larger for developing countries than for the developed world (as one may argue biotechnology is, tropical diseases is another, perhaps even more clear case), the importance of IPRs in developing countries is especially high. Given that the market for products based on these technologies is small(er) in developed countries, strong IPRs in the developed world may simply prove to be too small an incentive to stimulate R\&D (Van Wijk and Junne, 1993).

However, the 'old' concern that multinational companies from the developed world gain control over technologies that are crucial to the fate of developing countries, is also especially large in those cases. The World Bank (World development Report 1998/99, Box 2.6 and related text), discusses the issue of compensation when 'bioprospecting strikes gold'. Examples are mentioned of cases where large pharmaceutical companies from the developed world "appropriate valuable biomedical knowledge from indigenous peoples" (WDR, Box 2.6). However, a trend is also signaled in which companies provide compensation in the form of lump sum payments and/or royalty sharing to local communities. It seems to me that such a trend might well be formalized into international rules to prevent such 'reverse technology transfer' without adequate compensation.

\section{Summary and Conclusions}

This paper has made an attempt to outline some of the crucial issues in the debate on the role of intellectual property rights (IPRs) in technology transfer. Attention was devoted mainly to patents as a specific type of IPRs. The literature distinguishes four main reasons why strong worldwide IPRs may be beneficial for development. First, strong IPRs may stimulate invention in developing countries. Second, IPRs formalize opportunities for technology 
licensing by firms in developing countries. Third, strong IPRs enhance the incentive for firms from the developed world to engage in activities that entail technology transfer, such as foreign direct investment (FDI) and joint ventures with firms in developing countries. Fourth, developing nations that allow infringement of IPRs of firms from developed countries run the risk of retaliation by those countries in terms of trade policy, which hampers their prospects for export-based growth.

With the signing of the TRIPs agreement (part of WTO), relatively strong and worldwide uniform IPRs now seem the de facto situation. The paper provided three main points of discussion around the issues concerning TRIPs, IPRs and development. First, it was argued that economic theory does not provide a clear case for or against a system of harmonized IPRs, versus one with differentiated levels of protection. However, it is clear from the theory that the building up of domestic capabilities in the area of science and technology is an important prerequisite for developing countries to benefit from stronger worldwide IPRs (as implied in TRIPs). This led to recommendation that international organizations such as the World Bank, keep this issue high on the policy agenda (which is in fact done, see the World Development Report 1998/99). Also, it was suggested that WIPO may take an active role in this process by initiating research to clarify issues around IPRs and building up of domestic technological capability.

Second, it was argued that there are many channels by which technology flows between nations, and which are different from the channels as identified in the literature on IPRs and technology transfer (i.e., FDI and international trade). It was argued that technology flows may either be embodied (in trade goods, or FDI), or disembodied, and that evidence from the developed world shows that disembodied knowledge flows are relatively important. Increasing (worldwide) patent protection may hamper such disembodied knowledge flows, while at the same time increasing embodied flows, leaving the net effect unclear. Again, more (empirical) research seems to be necessary to assess the effects on technology transfer.

Third, it was argued that it may be useful to initiate negotiations to formalize proper compensation for the use of local knowledge from developing countries by biotechnology (and pharmaceutical) companies from the developed world.

\section{References}

Abramovitz, M. A. (1979). Rapid Growth Potential and its Realisation : The Experience of Capitalist Economies in the Postwar Period. Economic Growth and Resources, vol. 1 The major Issues, Proceedings of the fifth World Congress of the International Economic Association. E. Malinvaud. London, Macmillan: 1-51.

Abramovitz, M. A. (1994). The Origins of the Postwar Catch-Up and Convergence Boom.

The Dynamics of Trade, Technology and Growth. J. Fagerberg, B. Verspagen and N. Von Tunzelmann. Aldershot, Edward Elgar: 21-52.

Acharya, R. (1995). The Impact of New Technologies on Economic Growth and Trade. A Case Study of Biotechnology. Ph.D. thesis Faculty of Economics. Maastricht, University of Limburg. 
Chin, J. C. and G. M. Grossman (1990). Intellectual Property Rights and North-South Trade. The Political Economy of International Trade. Essays in Honour of Robert E. Baldwin. R. W. Jones and A. O. Krueger. Cambridge, Basil Blackwell.

Coe, D. T., E. Helpman, et al. (1997). "North-South R\&D Spillovers.” Economic Journal 107: 134-149.

Cornwall, J. (1977). Modern Capitalism. Its Growth and Transformation. London, Martin Robertson.

David, P. A. (1993). Intellectual Property Institutions and the Panda's Thumb: Patents, Copyrights, and Trade Secrets in Economic Theory and History. Global Dimensions of Intellectual Property Rights in Science and Technology. M. B. Wallerstein, M. E. Mogee and R. A. Schoen. Washington, D.C., National Academy Press: 19-64.

De Long, J. B. (1988). "Productivity Growth, Convergence and Welfare: Comment." American Economic Review 78: 1138-1154.

Deardorff, A. V. (1992). "Welfare effects of Global patent protection." Economica 59: 35-51.

Denison, E. (1966). Why growth rates differ. Washington, Brookings Institution.

Diwan, I. and D. Rodrik (1991). "Patents, Appropiate Technology, and North-South Trade." Journal of International Economics 30: 27-47.

European Commission (1998). The Second European Report on Science and Technology Indicators. Luxembourg/Brussels, European Commission, DG XII.

Fagerberg, J. and B. Verspagen (1998). Productivity, R\&D Spillovers and Trade, ECIS Working Paper 98-1.

Freeman, C. (1994). Technological Revolutions and Catching-Up: ICT and the NICs. The Dynamics of Trade, Technology and Growth. J. Fagerberg, B. Verspagen and N. Von Tunzelmann. Aldershot, Edward Elgar: 198-221.

Frischtak, C. R. (1993). Harmonization versus Differentiation in Intellectual Property Rights Regimes. Global Dimensions of Intellectual Property Rights in Science and Technology. M. B. Wallerstein, M. E. Mogee and R. A. Schoen. Washington, D.C., National Academy Press: 89-106.

Griliches, Z. (1979). "Issues in Assessing the Contribution of Research and Development to Productivity Growth.” The Bell Journal of Economics 10: 92-116.

Helpman, E. (1993). "Innovation, Imitation, and Intellectual Property Rights." Econometrica 61: $1247-1280$.

Jorgenson, D. W. and Z. Griliches (1967). "Explanation of Productivity Change." Review of Economic Studies 34: 249-283.

Klemperer, P. (1990). "How broad should the scope of patent protection be?" RAND Journal of Economics 21: 113-130.

Lichtenberg, F. and B. Van Pottelsberghe (1996). "International R\&D Spillovers: A ReExamination." NBER Working Paper 5668.

Maddison, A. (1987). "Growth and Slowdown in Advanced Capitalist Economies: Techniques of Quantitative Assessment." Journal of Economic Literature 25: 649-698.

Mansfield, E. (1993). Unauthorized Use of Intellectual Property: Effects on Investment, Trechnology Transfer, and Innovation. Global Dimensions of Intellectual Property Rights 
in Science and Technology. M. B. Wallerstein, M. E. Mogee and R. A. Schoen. Washington, D.C., National Academy Press: 107-145.

Mansfield, E. (1994). Intellectual Property Protection, foreign Direct Investment and Technology Transfer, International Finance Corporation Discussion Paper 19.

Mansfield, E. (1995). Intellectual Property Protection, Direct Investment and Technology Transfer: Germany, Japan and the United States, International Finance Corporation Discussion Paper 27.

Mody, A. (1990). New International Environment for Intellectual Property Rights. Intellectual Property Rights in Science, Technology and Economic Performance. F. W. Rushing and C. Ganz Brown. Boulder, Westview Press.

Nordhaus, W. D. (1969). Invention, Growth and Welfare. A Theoretical Treatment of Technological Change. Cambridge MA, MIT Press.

North, D. C. (1990). Institutions, Institutional Change and Economic Performance. Cambridge, Cambridge University Press.

North, D. C. and R. P. Thomas (1973). The Rise of the Western World. A New Economic History. Cambridge, Cambridge University Press.

Primo Braga, C. (1990). Guidance from the economic theory. Strengthening Protection of Intellectual Property in developing Countries. A survey of the Literature. E. W. Siebeck. Washington D.C., World Bank Discussion Paper no. 112.

Sherwood, R. M. (1993). Why a Uniform Intellectual Property System Makes Sense for the World. Global Dimensions of Intellectual Property Rights in Science and Technology. M. B. Wallerstein, M. E. Mogee and R. A. Schoen. Washington, D.C., National Academy Press: 68-88.

Siebeck, W. E., Ed. (1990). Strengthening Protection of Intellectual Property in Developing Countries: A Survey of the Literature. World Bank Discussion Paper 112. Washington D.C.

Soete, L. and B. Verspagen (1993). Technology and Growth: The Complex Dynamics of Catching Up, Falling Behind and Taking Over. Explaining Economic Growth. A. Szirmai, B. Van Ark and D. Pilat. Amsterdam, Elsevier: 101-127.

Solow, R. M. (1956). "A Contribution to the Theory of Economic Growth." Quarterly Journal of Economics 70: 65-94.

Solow, R. M. (1957). "Technical Progress and the Aggregate Production Function." Review of Economics and Statistics 39: 312-320.

Tinbergen, J. (1943). "Zur Theorie der Langfristigen Wirtschaftsentwicklung." Weltwirtschaftliches Archiv: 511-549.

UNCTAD (1975). The Role of the Patent System in the Transfer of Technology to Developing Countries. New York, United Nations.

van Dijk, T. (1994). The Limits of Patent Protection. Essays on the Economics of Intellectual Property Rights. Ph.D. thesis Faculty of Economics. Maastricht, University of Limburg.

Van Wijk, J. and G. Junne (1993). Intellectual Property Protection of Advanced Technology. Changes in the Global Technology System: Implications and Options for Developing Countries. Maastricht, UNU/Intech Working Paper 10. 
Verspagen, B. (1991). "A New Empirical Approach to Catching Up or Falling Behind." Structural Change and Economic Dynamics 2: 359-380.

Wallerstein, M. B., M. E. Mogee, et al., Eds. (1993). Global Dimensions of Intellectual Property Rights in Science and Technology. Global Dimensions of Intellectual Property Rights in Science and Technology. Washington, D.C., National Academy Press.

World Bank (1998). World Development Report. Knowledge for Development. 1998/1999. Oxford, Oxford University Press.

Yankey, G. S.-A. (1987). International Patents and Technology Transfer to Less Developed Countries. The case of Ghana and Nigeria. Aldershot, Avebury. 